\title{
THE CONCEPT OF USURY (RIBĀ) ACCORDING TO MTR
}

\author{
Sri Wigati \\ UIN Sunan Ampel Surabaya
}

sriwigatiwiwik@gmail.com

\begin{abstract}
Of the many anti-usury movements in Indonesia, one of them is a community called the Society Without Usury (Masyarakat Tanpa Ribā hereinafter referred to as MTR). This community already has networks in several regions in Indonesia, which carry out the mission of da'wah to spread the understanding of usury and help people who are caught in problems with usury. The existence of this community aims to become a place of consultation as well as complaints for victims of usury. This research was conducted to answer the questions; What is the history of the emergence of MTR which echoes the spirit of living without usury? The type of this research is a qualitative research and uses field research. The approach that used in this research is phenomenology approach which sees changes in people's ways of thinking in life. Data collection techniques in this research are participatory observations, interviews and documentations. The results of this research show that: the history of the emergence of MTR is due to awareness as an anti-usury da'wah community, social movement, self-liberation from debt.
\end{abstract}

Keywords: Usury, Society Without Usury (MTR)

\begin{abstract}
Abstrak: Dari sekian banyak gerakan anti riba di Indonesia, salah satunya adalah komunitas bernama Masyarakat Tanpa Riba (selanjutnya ditulis MTR). Komunitas ini sudah mempunyai jaringan di beberapa daerah di Indonesia, yang membawa misi dakwah menyebarluaskan pemahaman tentang riba dan membantu orang-orang yang terjerat masalah dengan riba. Keberadaan komunitas ini sebagai tempat konsultasi sekaligus aduan bagi korban riba. Dalam penelitian ini dilakukan untuk menjawab pertanyaan: pertama, bagaimana bagaimana sejarah munculnya Masyarakat Tanpa Riba (MTR) dengan menguatkan hidup tanpa riba? Penelitian ini merupakan jenis penelitian kualitatif dan menggunakan penelitian lapangan (field research). Pendekatan yang digunakan adalah fenomenologi. Dalam pengamatan melihat perubahan cara berfikir masyarakat dalam kehidupan. Teknik pengumpulan data dengan observasi pastisipatif, wawancara dan dokumentasi. Hasil penelitian menunjukkan bahwa: sejarah munculnya Masyarakat Tanpa Riba karena adanya kesadaran sebagai komunitas dakwah anti riba, gerakan sosial, pembebasan diri dari hutang.
\end{abstract}

Kata Kunci: Riba, Masyarakat Tanpa Riba (MTR)

\section{maliyate}

Jurnal Hukum Bisnis Islam

Volume 11, Nomor 02, Desember 2021

p-ISSN: 2088-4869/ e-ISSN: 2597-4351 


\section{Introduction}

Currently, Indonesian Muslims are very strong in implementing the teachings of Islamic Economics. That's because in 1991 emerged an idea to form a sharia-based financial institution in the form of a bank with a paid-up capital of Rp. 106,126,382,000. On May 1, 1992, with this capital, Bank Muamalah Indonesia (BMI) was officially opened and ready to operate with the support of President Suharto, who at that time also contributed to the investment of $1 \mathrm{M}$ shares. The presence of Bank Muamalah Indonesia (BMI) is the main trigger for the growth and development of Islamic banks in Indonesia. Until now, Islamic banking is widespread throughout the country with the presence of a number of Sharia Rural Banks (BPRS), Islamic banks that offer Islamic banking services (dual system) and Baytul Māl Wa at-Tamlīk (BMT). ${ }^{1}$

In the Qur'an, there are verses that explain the prohibition of the law of usury, these verses include Surah alRum once in verse 39 , Surah al-Nisa' once in verse 161, Surah Ali Imran once in verse 130, surah al-Baqarah three times in verses 275,276 and $278 .^{2}$

As for the group of scholars who forbid bank interest, include both those who keep their money in banks and borrowers of money in banks. The group was Muhammad Abu Zahrah, Abu A'la al-Maudūdī, Muhammad Abdul al-Arab and Muhammad Nejatullah Siddqī. According to Muhammad Nejatullah Siddiq, bank interest is one of the sources of many economic evils, such as monopolistic practices. ${ }^{3}$

The controversy about usury until now has not subsided. Some scholars are sensitive when discussing this

\footnotetext{
${ }^{1}$ A. Ridwan Amin, Perbankan Syariah sebagai Solusi Perekonomian Nasional (Jakarta: UIN Press, 2009), 24.

${ }^{2}$ Mujar Ibnu Syarif, Konsep Riba dalam al-Qur'an dan Literatur Fikih, Jurnal alIqtishad, Vol 3 No.2, Universiti Malaya, Malaysia: July 2011.

${ }^{3}$ Muhamad Sadi Is, Konsep Hukum Perbankan Syariah (Malang: Setara Press, 2015), 10
} 
issue. But on the other hand, there are also some scholars who ignore the understanding of usury by considering it an old and outdated discussion. ${ }^{4}$ The debate about usury has been approached by many aspects, one of which is about bank interest which is considered as a reasonable thing, which is economically converted into a capital interest rate with an additional (usury) as an excessive act that leads to extortion. Some scholars call it usury. While the majority of scholars say that the Qur'an prohibits and is considered as usury if there is an increase or additional amount of money returned by the debtor (borrower).

Modern economists put forward the requirements in the last few decades, namely a state of emergency (darürah) and public interest (mașlaḥah). According to Fazlur Rahman, if people cannot return to Islamic principles, then the effort to abolish bank interest is an action that will kill the economic welfare of the people and state finances. This is very contrary to the verse mentioned in the Qur'an and Sunnah. ${ }^{5}$

Some scholars argue that many people misunderstand the concept of usury such as misinterpretation and application of the concept of usury. One of the scholars, Muhammad Sa'id al-Asmawi ${ }^{6}$ expressed his opinion about the prohibition of interest, namely a) interest referred to in the Qur'anic verse is usury nasi'ah (ribā an-nasīah). b) Ribā in the hadith consists of six kinds of objects. c) there is a difference between productive and business loans in order to invest as well as those that generate profits.

Some scholars contradict what has been mentioned above, they argue that to avoid usury in a modern economy,

\footnotetext{
${ }^{4}$ Anwar Iqbal, Islam and the Theory of Interest (Lahore: Ashraf, 1974), 4

5 Edward Mortimer, Faith and Power: The Politics of Islam (New York: Random House, 1982), 245.

${ }^{6}$ William E. Shepard, "Muhammad Sa'id al-Asmawi and the Aplication of the Shari'ah al-Qur' an in Egypt", International Journal of Middle East Studies, 28, (1996), 46.
} 
they can use appropriate mechanical techniques. ${ }^{7}$ But this is stated not to solve the problem, it actually exacerbates and prolongs the existing controversy. In 1904, Muhammad Abduh, one of the mufti who came from Egypt brought about rapid economic changes. He issued a controversial fatwa established by the postal administration regarding the Egyptian savings fund (sandūq at-tafwīr). The fatwa maintains a cautious view of the interest that has been previously set. ${ }^{8}$

Although a lot of balancing efforts have been made, it seems that all forms of conflict still cannot be appeased. In 1986, the Islamic conference fiqh academy condemned all transactions related to interest as unacceptable. But in 1989 when the economic and rhetorical debate between Islamic financial institutions and conventional banks was getting worse and hotter, Muhammad Sayyid 'Ațiyya Tanțawi (an Egyptian mufti) issued a fatwa which he thought was important, namely to legitimize capitalist certificates, in which interest-bearing state bonds were borne by banks, banks that located in Egypt. He said that the previous interest determination was in the interests of the capital owner and this was done because it was to protect the dispute between the capital owner and the bank. ${ }^{9}$

In modern life it is very difficult to leave the world of banking, or financial institutions. Life is no longer enough with barter type transactions. Exchange is no longer between goods for goods. So there is something greater with the needs of the past. Needs develop from tertiary to secondary, secondary to primary. This is in line with technological and economic progress. Islam is the religion of Allah which is full of guidance to achieve happiness in this world and the hereafter. Islam is

\footnotetext{
${ }^{7}$ Chibli Mallat, The Renewal of Islamic Law: Muhammad Baqer as-Sadr, Najaf and Shi'i International (London: Cambrige University Press, 1988), 162-184.

${ }^{8}$ Chibli Mallat, "The Debate on Riba and Interest in Twentieth Century Egypt", dalam Chibli Mallat (ed). Islamic Law and Finance (London: Graham and Trotman, 1988), 68-88.

${ }^{9}$ Fuad Omar and Mohammed Abdel Had, Islamic Banking: Theory, Practice and Challenges (London: Zed Books, 1996), 8.
} 
also a religion that regulates all human problems on this earth. All instructions are based on the Qur'an and al-Hadith, but not all instructions given by Islam are ready to be implemented. As for certain issues, according to some scholars, it is necessary to conduct ijtihād. Ijtihād is devoting all abilities to obtain operational Islamic law through istinbāț. ${ }^{10}$ There are still many problems in this world that require a solution, such as the problem of usury when faced with bank problems. On the one hand, bank interest is one of the criteria of usury, but on the other hand, its presence is very necessary to improve the economy of muslims whose position is still in the feasibility line, especially when compared to the economy in general. ${ }^{11}$

The banking world is currently causing a lot of controversy about its legal status when it comes to bank interest and usury. Muslims often feel a dilemma when faced with this problem. What becomes a burden on the mind is whether bank interest is halal, haram or doubtful (syubhah)? While what is mentioned in the Qur'an and hadith is only the word usury, it does not mean that usury is the same as interest. Therefore, the issue of bank interest is still included in the ijtihaddiyyah category, which means that in each of these problems it still requires the role of reason from the Islamic law scholars through the ijtihād method. ${ }^{12}$ Currently, banks have many functions, one of which is as a means of liaison between owners of capital and entrepreneurs. To be able to continue to develop their business, entrepreneurs usually use the services of a bank that aims to meet their business capital according to the amount needed. In this regard, financial institutions are stated to be very important buffers in the modern economic system. While the banking world itself has a

\footnotetext{
${ }^{10}$ Yusuf al-Qardawi, Ijtihad dalam Syariah Islam, Cet ke 1 (Jakarta: Bulan Bintang, 1987), 2.

${ }^{11}$ Muh. Zuhri, Riba dalam al-Qur'an dan Masalah Perbankan (Jakarta: PT. Raja Grafindo Persada, 1992), 4.

${ }^{12}$ Wakum, BMUI dan Takaful Indonesia (Jakarta: Raja Grafindo Persada, 1996), 166.
} 
main characteristic, namely by using the interest system, the question that many people ask is what is the law for bank transactions that apply the interest system?

By looking at the debate in the area of usury, the antiusury movement and slogan began to spread among Indonesian Muslims, with the spirit of anti-usury each community has a different vision and mission, but the goal remains the same, namely increasing public awareness of the dangers of usury. The history of the Islamic economic movement, especially in Indonesia, from the pre-independence era until now has different characteristics. But each movement describes the mission of nationalism, solidarity, religion and Islamization. In the pre-independence period until independence, the Dutch colonialism gave rise to nationalism and religion. Nationalism was directed as a response to Dutch colonialism which discriminated against the indigenous population. Meanwhile, religion is used for the movement of the Muslim community, especially in the Java and Sumatra regions to raise the spirit of religious unity and independence. Entering the post-independence era to reformation, this Islamic economic movement is more concentrated with the existence of religious organizations that only aim for the welfare of the people and da'wah.

However, socio-political conditions in Indonesia cannot be separated from it, it is quiet influential on the phenomenon of Indonesia's economic movement. Like the political system of the Dutch East Indies government, non-indigenous (Chinese) economic agents, the existence of culture and religion greatly colored this movement. Islamic economic movements are classified into two types, namely the pre-independence period and the post-independence period. The pre-independence period was more inclined to religious nationalism, especially in business competition with non-indigenous groups such as Chinese and Arab countries which were given special space by the Colonial Government. While the post-independence period is a period of consolidation of religious groups such as Muhammadiyah and NU as well as socio-economic institutions

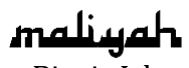


with the establishment of BMT and ZISWAF institutions (zakāh, infāq, waqf and șadaqah).

At that time, the debate about usury had already started, which was originally only a response to the issue of the lawfulness of bank interest, and was developed by holding a seminar in 1968 to discuss the involvement of Muslims in the world of development politics and business. Issues regarding usury were also discussed and discussed by expressing views regarding the halalness of banks so that the Islamic community can obtain loan funds for business. Various kinds of seminars and discussions regarding usury and bank interest have continued and developed to this day, and from these crossgenerational discussions, movements with an ideological background of understanding related to usury and interest law in banking activities in Indonesia were born.

Among the movements referred to discussions above is the anti-usury movement which is escorted by the MTR. The MTR is part of the Sharia World Community (Kampung Syarea World hereinafter referred to as KSW). KSW started as a community of developers, landlords, and businesses in the real estate and property sector. KSW has one strong principle, namely wanting to develop a sharia business without the frills of usury, without debt and other vanity contracts. KSW also tries to avoid contracts that are prohibited by sharia. The more sophisticated the technology today, the wider MTR has grown until now. MTR has been formed in almost 70 cities in Indonesia, anyone can join as a member of the MTR with the terms and conditions that have been determined. The emergence of MTR is motivated by two main reasons, namely: first, concern for Indonesia, a country whose population is predominantly Muslim but systematically and massively legalizes usury through the existence of conventional banks. So that the majority of people, especially Muslims from all walks of life, have fallen into usury transactions in all lines of life, even the saddest has become a lifestyle that they are proud of. 
Second, this movement is motivated by awareness on the basis of the concept of brilliant thought (Islamic Aqeedah) to awaken Indonesian Muslims from multidimensional adversity, especially the traps and entanglements of usury. Their movement is based on QS. Ali Imron verse 104. This thought is based on a clean-sound-sincere faith, far from worldly tendencies, and is applied in the form of community strength as the realization of Ummah obligations.

MTR as an anti-usury da'wah community has a unique perspective compared to other anti-usury movements. MTR views all kinds of usury as haram. In practice, MTR focuses on educating the awareness of Muslims to obey sharia by printing booklets or mini books that discuss the 20 major sins of usury in the world and 10 major sins in the hereafter in all lines of muamalah usury transactions in banking, stock exchanges, insurance, leasing, pawnshops, foreign exchange, cooperatives, and other financial institutions. ${ }^{13}$

MTR's perspective on Islamic banks is also different, MTR concludes that Islamic banks are the same as conventional banks. MTR considers that all transaction contract names in Islamic banks have only changed terms into Arabic from conventional contracts. So according to him, the existence of Islamic banks is not or cannot be a solution to abolish the practice of usury.

In addition, MTR views that bank interest in conventional banks is the same as usury. Because according to them interest is the process of asking for additional money from the initial loan, both in buying and selling transactions and debts and receivables and it is against sharia principles. The MTR community itself refers to the view of the Majelis Tarjih Muhammadiyah, namely prohibiting the practice of interest in banks based on the text (nas al-sarịh) of the Qur'an and hadith. Thus, the members of the MTR established a

\footnotetext{
${ }^{13}$ www.masyarakattanpariba.com diaskes pada tanggal 13 November 2018.
} 
movement to reject the practice of usury in order to save and eradicate ummah from the problem of usury.

The presence of the MTR community in the community, both on social media and direct da'wah in the community, currently exists enough. There are so many interaction activities between one person and another, one form of this interaction is in the WAG (WhatsApp Group). In addition, MTR also has several da'wah activities such as fiqh al-mu'āmalah studies which are held every month guided directly by Ustadz Shiddiq Al-Jawi, he is one of the MTR community coaches. and others there is an activity of distributing information brochures related to MTR events. The event is in the form of educational seminars, training and workshops, as well as meetings between entrepreneurs and MTR residents in each city. The members of the MTR community who attended were able to convey their concerns or problems related to debt \& usury.

This research is field research, which means research that reveals and combines the facts of the social life of the people who are in the field directly with direct observation, interviews and using a bibliography. ${ }^{14}$ The research method used in this research is the phenomenological method, which emphasizes the changes in people's way of thinking about life. ${ }^{15}$

This method uses inductive phenomenology which is used to examine objects or phenomena such as thoughts, perceptions, beliefs and desires about something outside the subject or something transcendent. ${ }^{16}$ Starting from the explanation above, the researcher tries to reveal the aspects and forms of MTR activities in the formation of community character that is truly free from interest and usury.

\footnotetext{
${ }^{14}$ Marheyani, Metode Penelitian (Jakarta: PT. Bumi Perkasa, 2005), 25.

${ }^{15}$ Nana Syaodih Sukmadinata, Metode Penelitian Pendidikan(Bandung: Remaja Rosdakarya, 2010), 14.

${ }^{16}$ Noeng Muhadjir, Metodologi Penelitian Kualitatif, edisi V (Yogyakarta: Rake Sarasin, 2007), 137.
} 
The second stage is through an evaluative stage approach or also called descriptive-analytic. What is meant by descriptive-analytic is selecting and classifying the basic parts of the concept of MTR that have been integrated with the learning activities carried out and seeing what steps will be taken in the process of forming the character of the members of MTR.

The definition of the qualitative method used in research is a research method that uses a natural research object, where a researcher is the key instrument. The data collected is done in a combined manner (triangulation). Triangulation is used as a technique to collect data that combines several data collection techniques and data sources that are already available, then it will be analyzed inductively and the results of this qualitative research emphasize more on its meaning than generalization. ${ }^{17}$

\section{Definition of Rib̄a}

Riba comes from arabic words, which is derived from the word rabā-yarbū-rabwan, which means al-ziyādah (additional) or al-faḍl (excess), growing (al-numuww), increasing (al-irfā') and growing (al-'uluw). ${ }^{18}$ In other words, usury is the increase, development, addition and enlargement of the principal loan provided by the borrower to the recipient of the loan as a form of reward for suspending part of his capital for a certain period of time.

In the book of Fiqh al-Sunnah, Sayyid Sabiq defines usury as an addition to capital, whether the addition is a little or a lot. Ibn Hajar 'Asqalani also defines usury as an excess in the form of money or goods. According to Mahmud al-Hasan Taunki, usury is an excess or addition to a contract for the

\footnotetext{
${ }^{17}$ Sugiyono, Metode Penelitian Kuantitatif Kualitatif dan $R \& D$ (Bandung: Alfabeta, 2011), 21.

${ }^{18}$ Ahamad Warson Munawir, "Kamus Bahasa Arab-Indonesia al-Munawir (Yogyakarta: Pustaka Progresif Pondok Pesantren al-Munawir, 1984), 504.
} 
exchange of goods for which more than one item is requested in exchange for the same item. ${ }^{19}$

Currently, usury is known as an additional form accompanied by compensation which is prohibited by Islam. In the Qur'an, it has been explained in detail the stages of prohibiting usury. First, it describes the existence of negative elements in usury which is stated in the Qur'an al-Rum (30) verse 39. Second, the sign of the prohibition of usury by conveying criticism of the Jews who practice usury is stated in the al-Qur'an letter al-Nisa (4) verse 161. Third, the Qur'an explicitly forbids usury with the limits of ad'äfan muḍa'afan listed in the Qur'an Surah Ali Imran (3) verse 130 which is followed by the total prohibition of usury in its various forms mentioned in Surah Al-Baqarah (2) verses 278-281.

Quraish Shihab said, usury in terms of language means "excess". If we only focus on the meaning of this word, then the thoughts expressed by the opponents of usury at the time of the prophet can be said to be true. At that time they said "buying and selling is the same as usury" as in the verse of the Qur'an surah al-Baqarah (2) verse 275. Allah answered them firmly that "Allah has permitted buying and selling and forbids usury". The confirmation of the answer from Allah does not clearly state the reason, but it can be seen that there are certain reasons so that buying and selling is allowed but usury is prohibited. In another work, Quraish Shihab also asserts that the prohibition of usury, as stated in the Qur'an, is inseparable from three views, namely (a) aḍ'āfan muḍā'afan, (b) mā baqiya min al-ribā and (c) falakum ru'usu amwālikum, là tazlimūna wa la tuzlamūn. ${ }^{20}$ If it is brought into the study of fiqh, then the reason for the prohibition of usury is the multiplied element and the element of persecution in determining the excess of repaying the debt.

\footnotetext{
${ }^{19}$ Heri Sudarsono, Bank dan Lembaga Keuangan Syariah (Yogyakarta: Ekonisia, 2004), 10.

${ }^{20}$ M. Quraish Shihab, Membumikan al-Qur'an (Bandung: Mizan, 1995), 261.
} 
Meanwhile, Badruddin al-Aini argues that the main principle in usury is addition. According to sharia, usury means addition to the cost of goods without any real business transactions. ${ }^{21}$ Meanwhile, according to Zaid bin Aslan, what is meant by ribā jāhiliyyah which implies multiplication over time is someone who has receivables from his partner then he said on due time "pay now or add". ${ }^{22}$ And Imam Ahmad bin Hanbal when asked about usury, he replied, "Indeed, usury is someone who has a debt, so it is said to him whether to pay it off or pay more. If he is unable to repay, he must add funds (in the form of loan interest) for the additional time given. ${ }^{23}$

From the explanation above, it can be concluded that there is a common thread between the terminology and epistemological understanding that usury is an addition to the main assets taken without any substitute transactions received with the addition of the assets.

Islamic economics is the result of the thoughts of Muslim leaders based on the Koran and hadith. Islamic economics is an economic system that explains all kinds of behavior, phenomena, choices and decision making in every economic activity or activity based on Islamic ethics and morals. In order to achieve the success of Islamic economics, what we need to do is get to know these sciences by using one way such as knowing classical and modern figures who gave their thoughts on the development of Economics.

\section{Classic Thought on Ribā}

The discussion of usury has actually been discussed for a long time and has undergone many developments in its

\footnotetext{
${ }^{21}$ Badruddin al-Ayni, Umdah al-Qari, Konstantinopel: Mathba'ah al-Amira, vol.V, 1310, 436.

${ }^{22}$ Al-Qurtubi, Al-Jami'li Ahkam Al-Qur'an, juz IV (Kairo: Dar al-Katib al'Arabi, 1967), 202, al-Thabrani, Jami' al-Bayan fi Tafsir al-Qur'an, juz VII (Mesir: Musthafa al Babi al Halabi, 1968), 204.

${ }^{23}$ Ibnul Qayyim al-Jawziyyah, I'lam al-Muwaqi'in, jilid 2 (Beirut: Dar al-Kutub al-'Ilmiyah, t.t), 132.
} 
meaning. The issue of usury is not only discussed by Muslims, but also from various non-Muslims who see this problem seriously. We need to look at it from a historical perspective because usury has been happening since the days of jahiliyyah.

During the jahiliyyah, usury that was practiced was rib $\bar{a}$ an-nasiah. As quoted by Mannan, Imam Malik said that what is said to be usury is when at a certain time in a certain period and the time has expired, the lender asks the borrower, will he be on time to repay his loan or increase his loan? If he is willing to repay the debt, it will be accepted by the lender, but if he does not fulfill his loan payment, then the lender will give an extension of time and increase the amount owed. ${ }^{24}$

Likewise, Imam Razi stated, during the jahiliyyah period, people easily could lend their money and get additional money every month without affecting the amount of money given to the borrower. When the repayment is due, it will ask for the principal amount of the loan that he gave and if the recipient of the debt cannot return it, then the lender will automatically provide an extension of time and will increase the loan nominal for the benefit he gets. Anwar Iqbal al-Quresi told how the trade transaction habits of the Arabs before Islam were as follows:

1. If there is someone who wants to borrow goods or money from someone else with an agreement that the payment can be made on a mutually agreed date, if the borrower cannot pay it at the specified time, then the lender will provide an extension of time by condition that the borrower provides an additional amount. money for the extension of time that has been given to him.

2. If there is someone who wants to borrow a certain amount of money within a certain period of time on condition that when it is due, the borrower must pay the principal and the additional amount.

\footnotetext{
${ }^{24}$ Muhammad Abdul Mannan, Islamic Economics: Theory and Practice, Terj. M. Nastagin (Yogyakarta: PT. Dana Bhakti Wakaf), 119.
} 
3. The lender and the borrower agree on the amount of an additional rate in the form of usury within a certain period of time. If the borrower cannot pay off the debt with an additional amount when due, then the borrower must pay additionally in addition to the grace period that has been given. ${ }^{25}$

From the explanation given by Anwar Iqbal al-Quresi above, we can see that the practice of usury in the Jahiliyyah era was originally qard al- hasan, namely the loan that was returned was only a principal amount of the loan amount without any additions. Then, the additional practice of usury only appears when it is due but the borrower is unable to pay it. So at that time the lender will give additional time and the borrower agrees on the condition that the borrower adds an additional amount to the extension of time he has received. Gradually the practice of usury becomes a multiplier addition, the longer the loan period, the greater the loan amount until the wealth owned by the borrower is sucked in with the additional time he gives.

This was naturally practiced at that time, then came the religion of Islam which forbade the practice because it caused many unfavorable impacts on the development and economic growth of the community. The prohibition of usury by Islam did not immediately change rapidly, but proceeded slowly and gradually. This policy was one of the Koran's understandings of the condition of Arab society at that time. Of course it requires a long process and time because this practice is considered normal because it is very profitable.

Non-Muslim circles such as Jews, Christians, Greeks and Romans also discussed the issue of usury seriously. Ribā was originally something that was strictly prohibited in their religion which then gradually changed due to human greed.

1. Greek Philosopher

\footnotetext{
${ }^{25}$ Anwar Iqbal Quresy, Islam and Theory of Interest (Lahore, India: S.M Ashraf Publ, 1946), 49.
} 
The great Greek philosophers regarded usury as unfair. There are several Greek philosophers who expressed their thoughts on this including: (a) Plato (427-347 BC). In his "Laws" Plato denounces usury. There are two main reasons expressed by Plato. The first is that Plato considers usury to be the cause of destruction and feelings of always being lacking in his society. Second, Plato considers usury as a tool to exploit poverty. ${ }^{26}$ (b) Aristotle (384-322 BC). Aristotle, In his work "Politics", depicts usury with a hen that is sterile and cannot lay eggs. The point is that a piece of money cannot give birth to a piece of money. Usury is an unreasonable profit and cannot be classified as a legal trade. The function of money is as a medium of exchange. Making it as an object that is traded is not in accordance with the function of money itself. Aristotle asserts that money is not a means to earn extra through interest.

2. Roman Philosophers

There are some Roman philosophers such as: (a) Cato (243149 BC). Cato cursed the Romans who practiced usury picking. He provides two illustrations to illustrate the difference between commerce and lending. First, commerce is a risky job, while lending with usury is inappropriate. Second, there is a comparison between a thief and a usuryeater. Thieves will be fined double, while usury eaters will be fined four times; (b) Cicero (106-43 BC). Cicero also condemned the Romans who practiced usury. He advised his son to stay away from two jobs including giving loans with usury. Entering the Roman era which lasted from about the 5 th century $\mathrm{BC}$ to 4 th $\mathrm{AD}$, there was a rule derived from the law to allow the Roman population to enjoy the usury as long as the usury in accordance with the "maximum legal rate".

In Roman times there were four types of usury rates, but the value of usury rates was not fixed and varied with time.

\footnotetext{
${ }^{26}$ Muhammad Syafi'i Antonio, Bank Syariah dari Teori ke Praktek (Jakarta: Gema Insani, cet I, 2001), 44.
} 
Taking the usury rate is not allowed if using a doublecountable system (usury bearing interest). The usury rates in question are: (1) Maximum usury allowed 8\% - 12\%; (2) Average loan usury in Rome 4\% - 12\%; (3) Usury in Roman conquests $6 \%-100 \%$; (4) Byzantine special usury $4 \%-12 \%$. So the reasons for the Roman philosophy of refusing usury are not much different from those of the Greeks. They both think that usury are something despicable and vile.

3. Jews

The Jews in their scriptures are actually also prohibited from practicing interest taking, both in the Old Testament and Talmudic laws as quoted by Syafi'i Antonio in his book "Sharia Bank from Theory to Practice", namely: ${ }^{27}$ The Book of Exodus chapter 22 verse 25 states: "If you lend money to one of My people, the poor among you, then do not act as a debt collector against him, do not burden him with money." The Book of Deuteronomy chapter 23 verse 19 states: "You shall not give interest to your brother, neither money nor food, nor anything that can be accrued". And The Book of Leviticus chapter 25 verses 36-37 states: "Do not take interest or usury from it, but you must fear your God, so that your brother may live among you. Do not give your money to him by asking for interest, nor do you give your food by asking for usury."

The holy book that was originally a handle, they changed. They only forbid usury against the Jews. As for their dealings with non-Jews regarding usury, they are allowed. In the Talmud as quoted by Kahar Mansyur it is said that Moses taught firmly, "it is obligatory to lend to non-Jews with usury", there is also, "you may deceive non-Jews, you lend by taking that abominable usury. But if you sell or buy

\footnotetext{
${ }^{27}$ Kahar Mansyur, "Beberapa Pendapat Mengenai Riba” (Jakarta: Kalam Mulia, 1999), 33.
} 
something from your close fellow Jew, then don't deceive him and bargain with him." 28

4. Christian

During the millennial history of Christianity, according to the theologians, scholars and statutes, the practice of usury was strictly prohibited from their point of view. However, the practice of usury itself is indeed very difficult to eliminate, so various authorities are forced to make compromises by restricting and regulating the money-interest business. In the book of Luke 6: 34-35 (Book of Christianity) mentions a verse containing the prohibition of the practice of usury:

"And if you lend something to another, because you expect and ask something of him, what is your merit? Sinners also lend to sinners, so that they receive back the same amount. But have mercy on your enemies and do good to them and lend without expecting anything in return, and your reward will be great and you will become children of the Most High God, for He is kind to the ungrateful and to the wicked."

In the thought of a theologian after the time of Thomas Aquinas there was an attempt not to practice usury, namely by way of cooperation between one person and another. One person can lend their money as business capital to be played, for example to produce goods or sell. With an agreement that the owner of the capital will make a profit, but if it suffers a loss, the owner of the capital will also bear it. This method is not considered as collecting usury. This practice is known as profit and sharing. ${ }^{29}$

From the Christian religious leaders gradually emerged the interpretation of whether or not it was permissible to practice usury. Therefore, it is divided into three periods of perspective of Christian religious figures, namely: (1) The views of the early Christian clergy (I - XIII centuries); (2) The

${ }^{28}$ Zafarul Islamkhan, Talmud: Sejarah dan Ajarannya(Jakarta: Pustaka Hikmah Perdana, 2006), 79.

${ }^{29}$ M. Dawam Rahardjo, “Ensiklopedi al-Qur'an: Tafsir Sosial berdasarkan Konsep-konsep Kunci (Jakarta: Paramadina, 2002), 602. 
views of Christian scholars (XII - XVI centuries); (3) The views of the Christian reformers (XVI century -1836)

\section{Modern Thoughts on Ribā}

Modern Muslim scholars have different views regarding usury which has been explained in the Qur'an by applying usury in the form of interest. The visible difference is that it focuses on the following main problems: first, the element of injustice is the main issue in the prohibition so that the prohibition of usury is emphasized on the rational aspect. Second, the prohibition of the practice of usury based on the concept of Islamic law (fiqh). ${ }^{30}$

There are differences of opinion by the modernists with neo-Revival groups. The modernists are more inclined to the first view, while the neo-Revival groups are inclined to the second view. ${ }^{31}$ Wahba al Zuhayli defines usury as follows:

"Ribā is a surplus of commodity without counter-value in the commutative transaction of property for property. The intent of such a transaction is a surplus of commodities. Therefore, the definition of ribā includes both credit ribā and invalid sales, since postponement in either of the indemnities is a legal surplus without perceivable material recompense, the daley usually due to an increase in compentation. In Isla, money-money transactions are not allowed and there is no time value of money concept". ${ }^{32}$

In the book Ahkamul Qur'an, Qadi Abu Bakr Ibn Al'Arabī expresses the meaning of usury as an uncorrected addition to the value of the goods handed over to the counter

\footnotetext{
${ }^{30}$ Abdullah Saeed, Bank Islam dan Bunga: Studi Kritis dan Interpretasi Kontemporer tentang Riba dan Bunga(Yogyakarta: Pustaka Pelajar, 2003), 72.

${ }^{31} \mathrm{Neo}-$ Revivalis adalah kelompok yang memberikan respon terhadap pemikiran modernism klasik. Pandangan Neo-Revivalis berpijak pada penafsiran tradisional yang menekankan bahwa setiap bunga adalah riba.

${ }^{32}$ Wahba Al Zuhayli dalam Camille Paldi, 2014, Understanding Riba and Gharar in Islamic Finance "Journal of Islamic Banking and Finance, Vol. 31 July-Sept 2014 No. 3, International Association of Islamic Banks Karachi, Pakistan, 3637.
}

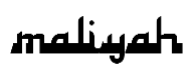

Jurnal Hukum Bisnis Islam Volume 11, Nomor 02, Desember 2021 p-ISSN: 2088-4869/ e-ISSN: 2597-4351 
value (of the goods received). ${ }^{33}$ That is, the value handed over in a transaction must be exactly the same and equal for both parties. In the book Bidāyatu al-Mujtahid, Ibn Rushd defines in detail eight transactions originating from usury, namely: (1) Sales transaction mixed with debt; (2) Transactions characterized by a statement "give me a leeway (in payment) and I will add (amount of return)"; (3) Sales transactions between gold and merchandise for gold; (4) Sales transactions with additions that are prohibited by syara'; (5) Transactions for reducing the amount of rewards so that settlements can be completed quickly; (6) Sales transactions are mixed up with the exchange of money; (7) Sales transactions with delayed payments are prohibited; (8)Sales transactions for food products that have not been received in full.

Muhammad Abduh is a character who first updated the notion of usury when he was still the Mufti of al-Azhar. The fatwa issued by him is "interest on savings is lawful". 34 "Riba as has been determined is absolutely not permissible, while the post office invests money collected from the community, which it does not take as debt on an as-needed basis, so it is possible to apply rules on profit sharing in investing on this kind of money"

From the statement in question, it can be seen that Muhammad Abduh began to shift the notion of interest as profit (on profit sharing), and therefore does not include usury. Then his student Rashid Rida classified usury into two groups, namely: (1) Ribā which has been stipulated in the Qur'an, and (2) Riba which has been determined in the Sunnah. ${ }^{35}$

Rashid Rida said that usury stipulated in the Koran is still haram and cannot be changed forever. According to Rashid Rida, usury stipulated in the Sunnah is lighter and secondary because it can be accepted in an emergency. Furthermore,

\footnotetext{
${ }^{33}$ Al-Arabi dalam Zaim Saidi, “Tidak Syar'inya Bank Syariah di Indonesia dan Jalan Keluarnya Menuju Muamalat" (Yogyakarta: Dekolomotif, 2010), 88.

${ }^{34}$ Muhammad Abduh, Risalah Tauhid(Jakarta: Bulan Bintang, 1963), 137.

${ }^{35}$ Muhammad Abduh dan Rashid Rida, Tafsir al-Manar(Beirut: Dar alMakrifah, 1975), 138.
} 
Rashid Rida explained that the usury mentioned in the Qur'an is usury jahiliyyah, meaning it is a habit that occurs in someone who cannot pay off his debts when they are due. Rashid Rida also equates this jahiliyyah usury with nasiah, he only associates usury with debts.

Rashid Rida teaches us that the law of riba an-nasiah is haram if it is multiplied. He also concluded that the interest charged by the bank is not unlawful and permissible. However, usury according to the Sunnah which is prohibited by religion

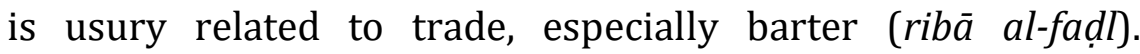
Another opinion that deserves to be criticized is the opinion expressed by Muhammad Syahrur regarding the theory of legal limits. In this theory, Syahrur introduces the study of usury in a good and detailed manner. By quoting several verses of the Koran related to the issue of usury. Syahrur explained that the meaning of usury in Arabic is "growth and development" of wealth.

Muhammad Syahrur said that Muslims do not need to hesitate and worry when they have to transact, in the banking world using the conventional system which uses an interest system, as long as the interest earned has not reached $100 \%$ of the initial capital. As a consequence of this analysis, Syahrur emphasized that the form of interest that is prohibited is because it includes usury if the interest reaches $100 \%$. Thus, as long as the interest is less than that amount, it is still in the permissible category, in the sense that the addition has not violated the limits of Allah's provisions. Such interest-bearing grants may not be given by other than banks, because it will lead to charging interest that exceeds government policy.

Based on the views of contemporary scholars put forward by these experts, we can see a change in the meaning of usury. Riba which is prohibited by religion is more emphasized on the practice of multiplying interest. Meanwhile, taking profits from borrowing and borrowing transactions based on the level of interest rates as determined by the government does not include usury, which is prohibited by religion and is legal. 


\section{Historical Analysis of the Emergence of MTR by Strengthening Life Without Ribā}

The birth of MTR was motivated by two main reasons. First, their concern for the country of Indonesia, where the people are predominantly Muslim, is systematically considered to have legalized usury so that the majority of the people, especially Muslims from all walks of life, have fallen into usury transactions in all walks of life. The saddest thing is that usury is a way of life to be proud of. Second, there is an awareness of the concept of brilliant thinking (Islamic Aqeedah) to awaken Muslims from multidimensional adversity, especially the entanglements of usury based on a clean-solid-sincere faith, far from worldly tendencies. The echo is getting busier and much talked about. Especially with the presence of MTR. ${ }^{36}$

The Qur'an has regulated humans in meeting all their material needs, how humans obtain their material needs, one of which is by transacting with other people, for example doing debts. Giving loans will help those in need as the principle of this loan or debt is to help. When there is an addition to the debt, it does not lighten the burden of others, but instead increases the burden of suffering. ${ }^{37}$

Muslims have agreed that loans or debts are prescribed in mu'âmalah. Because in debt there is an element of lightening the burden of others without expecting a reply. ${ }^{38}$ Meeting the needs of life is human nature, and fulfilling human needs cannot be separated from mu'ämalah activities that will meet their economic needs. Islam regulates regulating the economy in society so that profits are not only obtained by one party and the other party is harmed as is the case with garar.

The behavior of usury that occurs in society is strongly influenced by one's knowledge. The level of knowledge affects individual behavior. When an individual looks at an object and

\footnotetext{
${ }^{36}$ www.masyarakattanpariba.com diaskes pada tanggal 15 Mei 2019.

${ }^{37}$ Coach Budi, Wawancara, Purwokerto, 16 Oktober 2019.

${ }^{38}$ Imam Mustofa, Fiqih Muamalah Kontemporer (Jakarta: Raja Grafindo Persada, 2016), 171.
} 
tries to interpret what he sees. This interpretation is strongly influenced by the behavior of the individual's perception. Among the relevant personal characteristics influencing perception are attitudes, motives, interests and interests, past experiences and expectations.

Environmental elements also greatly influence the formation of people's perceptions of something. The presence of something new and different will cause perceptions that arise in the minds of individuals or communities who see and know it. The process of the emergence of perception in society sometimes causes an error in perceiving a certain object or stimulus.

According to the view of the MTR community, Islamic banks and conventional banks do not differ much in that all transaction contract names from conventional are replaced with Arabic terms, for example in conventional banks it is known as interest, then in Islamic banks it is known as nisbah (profit sharing). even in practice the calculation of the percentage value is higher in Islamic banks than conventional banks. According to MTR, Islamic banks and conventional banks in loan transactions are both stifling. So they advised MTR members not to bind themselves in the contract, please use a bank but with a savings contract.

\section{Closing}

Based on the analysis of research data findings, the authors can conclude as follows: The history of the emergence of MTR by strengthening life without usury is motivated by two main reasons, namely: first, concern for Indonesia, a country whose population is predominantly Muslim but systematically and massively legalizes usury through the existence of conventional banks. So that the majority of people, especially Muslims from all walks of life, have fallen into usury transactions in all lines of life, even the saddest has become a lifestyle that they are proud of. Second, this movement is motivated by awareness on the basis of the concept of brilliant thought (Islamic Aqeedah) to awaken Indonesian Muslims from multidimensional adversity, especially the traps and

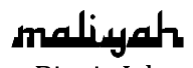


entanglements of usury. There is no consistency in the history of the emergence of MTR even though there are no statements of agreement and agreement with the banking system in Indonesia, both Islamic banks and conventional banks. However, MTR also does not appoint financial institutions in Indonesia which according to MTR are anti-usury and MTR itself also still uses the services of banks in Indonesia in their financial activities.

\section{Bibliography}

Abdul Hadi, Abu Sura'i Bunga Bank dalam Islam. Surabaya: AlIkhlas, 1993.

Amin, A. Ridwan. Perbankan Syariah Sebagai Solusi Perekonoian Nasional. Jakarta : UIN Press, 2009.

Antonio, Muhammad Syafi'i. Bank Syariah dari Teori ke Praktek. Jakarta: Gema Insani, cet I, 2001.

Aziz, Abdul. Dahlan, Ensiklopedi I I. I..... Islam. Jakarta : PT Ichtiar Baru Van Hoeve, 2010. 241

Baits, Ammi Nur. Ada Apa Dengan Riba?. Jogjakarta: Pustaka Muamalah. 2016.

Bank Indonesia. Islam dan Perbankan Syariah. Jakarta: Bank Indonesia, 2001.

Basyir, Ahmad Azhar. Hukum Islam tentang Riba, Utang Piutang dan Gadai. Bandung: al-Ma'arif, 1983.

Hatta, Moh. Beberapa Fasal Ekonomi Djalan Keekonomian dan Bank. Jakarta: Dinas Penerbitan Balai Pustaka, 1956.

Haque. Ziaul. Riba: The Moral Economy of Usury, Interest, and Profit. Malaysia: Ikraq 1995.

Harapan, Syahirin. Bunga Uang dan Riba dalam Hukum Islam. Jakarta: Pustaka al-Husna, 1993.

Is, Muhammad Sadi. Konsep Hukum Perbankan Syariah. Malang : Setara Press, 2015.

Karim, Adiwarman. Ekonomi Islam Suatu Kajian Kontemporer. Jakarta: Gema Insani, 2001.

Kasmir. Bank dan Lembaga Keuangan Lainnya, edisi keenam. Jakarta: Raja Grafindo Persada, 2002. 
Mannan, Muhammad Abdul. Islamic Economics: Theory and Practice, Terj. M. Nastagin. Yogyakarta: PT. Dana Bhakti Wakaf.

Mannan, Muhammad Abdul. Teori dan Praktek Ekonomi Islam. Yogyakarta: PT. Dana Bhakti Prima Yasa, 1997.

Mansyur, Kahar. "Beberapa Pendapat Mengenai Riba". Jakarta: Kalam Mulia, 1999.

Marheyani, Metode Penelitian. Jakarta: PT. Bumi Perkasa, 2005. Mirsel, Robert. Teori Pergerakan Sosial: Kilasan Sejarah dan Catatan Bibliografis. Yogyakarta: Resist Book, 2004.

Nazir, Habib dan Muhammad Hasanuddi. Inseklopedi Ekonomi dan Perbankan Syariah, cet. II. Bandung: Kafa Publishing, 2008.

Omar, Fuad and Mohammed Abdel-Had. Islamic Banking: Theory, Practice and Challenges. London: Zed Books, 1996. Purwaatmaja, Karnaen. "Apakah Bunga sama dengan Riba"?. Jakarta: LPPBS, 1997.

Purwataatmadja, Karnaen A dan M. Syafi'i Antonio, Apa dan Bagaimana Bank Islam. Yogyakarta:Dana Bakti Wakaf, 1992.

Qutb, Sayyid. Fi Zilail Qur'an, terj. Muhammad Abbas Aula, Dasar-dasar Sistem Ekonomi Sosial dalam Kitab Tafsir Fi Zilal al-Qur'an. Jakarta: PT. Pustaka Litera Antar Nusa, 1987.

Quresy, Anwar Iqbal. Islam and Theory of Interest. Lahore, India: S.M Ashraf Publ, 1946.

Ridha, Muhammad Rasyid. Tafsir al-Qur'an al-Hakim (Tafsir al Mannan) Jilid IV. Mesin: Dar al-Manar, $1376 \mathrm{H}$.

Saeed, Abdullah. Bank Islam dan Bunga: Studi Kritis dan Interpretasi Kontemporer tentang Riba dan Bunga. Yogyakarta: Pustaka Pelajar, 2003.

Saeed, Abdullah. Islamic Banking Interest a Study of the Prohibition of Riba and its Contemporary Interpretation, Terj. Muhammad Ufuqul Mubin, Nurul Huda, Ahmad Sahidah, Bank Islam dan Bunga (Studi Kritis dan Interpretasi Kontemporer tentang Riba dan Bunga). Yogyakarta: Pustaka Pelajar Offset, 2003. 
Sinungan, Muchsarsyah. Manajemen Dana Bank, edisi Kedua, cet IV. Jakarta: PT. Bumi Aksara, 2000.

Sjahdeini, Sutan Remy, Perbankan Syariah: Produk-Produk dan Aspek-Aspek Hukumnya. Jakarta: Prenadamedia Group, 2015.

Sudarsono, Heri. Bank dan Lembaga Keuangan Syariah. Yogyakarta: Ekonisia, 2004.

Sukmana, Konsep dan Teori Gerakan Sosial. Malang: Intrans Publishing, 2016.

Sutisna, Perilaku Konsumen dan Komunikasi Pemasaran. Bandung: PT Remaja Rosdakarya 2002.

Sudarsono, Heri. Bank dan Lembaga Keuangan Syariah: Deskripsi dan Ilustrasi. Yogyakarta: Ekonisia, 2003.

Sukarja, Ahmad. Riba, Bunga Bank dan Kredit Perumahan dalam Chuzaimah T. Yanggo dan Hafiz Anshori, Problematika Hukum Islam Kontemporer (Jakarta: Pustaka Firdaus, 1995.

Syahrur, Muhammad. Prinsip dan Dasar Hermeneutika Hukum Islam Kontemporer (terjemahan). Yogyakarta: eLSAQ Press, 2012.

Syadzali, Munawir. Ijtihad Kemanusiaan. Jakarta: Paramadina, 1997

Syarif, Mujar Ibnu: Konsep Riba dalam Al-Qur'an dan Literartur Fikih. Universiti Malaya, Malaysia: 26 Mei 2011.

Zuhrī, Muh. Riba dalam al-Qur'ân dan Masalah Perbankan, cet. ke-2. Jakarta: PT. Raja Grafindo Persada, 1992. 